\title{
USING AHP METHOD FOR EXPERTS PREFERENCE ANALYSIS IN RISK MANAGEMENT OF PROTECTED AREAS: A CASE STUDY IN VIETNAM
}

\begin{abstract}
From 1990 to 2015, the World's forest resources decreased 129 million ha (FAO, 2015). Globally, deforestation has continued to increase. To respond, reliable and up to date information on the state of forest resources is essential to support decision-making for investment and policymaking in both forestry and sustainable development. Many countries have developed protected area systems as a core strategy to protect national biodiversity and environment. The World Conservation Monitoring Centre rated Vietnam as the 16th most biologically diverse country in the world. A big challenge to biodiversity conservation in Vietnam is human disturbances of local communities living in the buffer zones and surrounding. An analysis of human factors and natural hazard was carried out with integration of AHP and GIS in spatial decision-making process. A sample model was developed in order to highlight the area where have the most problem.
\end{abstract}

Keywords: AHP, GIS, protected area, risk management

\section{Introduction}

The Bach Ma National Park (BMNP) is a protected area legally classed as special-use forests located in central Vietnam. The national park is regarded important for the conservation of a green corridor that stretches from the Vietnam-Lao border to the East Sea. However, illegal hunting and logging are still a relatively common problem in the BMNP. Forest thieves use waterways (streams, river) as a method to transport timber outside of the park. Besides illegal activities, other risks such as erosion and tourism activities are also counted as the negative impacts to the sensitive ecosystems of the Park. The study used AHP and GIS for modelling exposure to perturbation in the BMNP.

\section{Literature Review}

Decisions that need support methods are difficult by definition and therefore complex to model. A trade-off between prefect modelling and usability of the model has to be achieved. Among various MCDM techniques, the Analytical Hierarchy Process (AHP) (Saaty 1980) has reached this compromise. Integrating GIS and AHP is a powerful tool, which assists analysts and decision-makers to deal with the complexity of the spatial decision-making process (Murayama and Thapa 2011; Malczewski and Rinner 2015).

\section{Research Design and Model Analysis}

Structured interviews with nine experts were carefully selected so that they can provide the researcher with the required knowledge and cooperation. The experts selected must have several criteria such as have more than 10 years' experience in the research field and play a role as a decision maker in the BMNP. An aggregation of all nine judgments was accomplished based on geometric mean method. 
Using AHP method for experts preference analysis in risk management of protected areas: A case study in Vietnam

Table 1 Pair-wise comparison matrix of nine experts

\begin{tabular}{llllll}
\hline Indicators & Erosion & Hydrology & $\begin{array}{l}\text { Tourism } \\
\text { activities }\end{array}$ & $\begin{array}{l}\text { Illegal } \\
\text { logging }\end{array}$ & $\begin{array}{l}\text { Illegal } \\
\text { hunting }\end{array}$ \\
\hline Erosion & 1 & 1.318 & 0.627 & 0.159 & 0.205 \\
\hline Hydrology & 0.759 & 1 & 0.501 & 0.148 & 0.194 \\
\hline $\begin{array}{l}\text { Tourism } \\
\text { activities }\end{array}$ & 1.594 & 1.994 & 1 & 0.324 & 0.511 \\
\hline Illegal logging & 6.265 & 6.752 & 3.085 & 1 & 0.746 \\
\hline $\begin{array}{l}\text { Illegal hunting } \\
\text { Consistency }\end{array}$ & 4.871 & 5.150 & 1.956 & 0.572 & 1 \\
$\begin{array}{l}\text { Test } \\
(\mathrm{CR}<=10 \%)\end{array}$ & Eigenvalue $=5.025 \rightarrow \mathrm{CI}=0.006 ; \mathrm{RI}=1.11 \rightarrow \mathrm{CR}=\mathrm{CI} / \mathrm{RI}=0.006$ \\
\hline
\end{tabular}

The relative weights was calculated and showed the following result: (Erosion, Hydrology, Tourism activities, Illegal logging, Illegal hunting $)=(0.073,0.061,0.131,0.443,0.292)$. Each of those five factors of exposure was analysis separately and then combined together with weights respectively. A hot spots model was developed with help of GIS tool (see snapshot below).

\begin{tabular}{|c|c|c|c|c|c|c|c|c|}
\hline Layers and variables & $A$ & & & & & & & \\
\hline $\begin{array}{l}\text { की LineDen_Hydrology } \\
\text { क्षे EucDist_Hydrology }\end{array}$ & $\square$ & 7 & 8 & 9 & 1 & $==$ & $!=$ & \& \\
\hline $\begin{array}{l}\text { Output direction raster } \\
\text { Reda_LineDen_Hyd }\end{array}$ & & 4 & 5 & 6 & $*$ & $>$ & $>=$ & I \\
\hline Reclass_EucDis_Hyd & & 1 & 2 & 3 & - & $<$ & $<=$ & $\wedge$ \\
\hline $\begin{array}{l}\text { Redass_Erosion } \\
\text { rascal_Hyd }\end{array}$ & + & & & . & + & ( & ) & $\sim$ \\
\hline
\end{tabular}

\section{Conclusions and limitation}

The results shown that the most risk to the BMNP are focused on the area where close to boundary in the southwest of the BMNP. However, forest rangers are limited and many parts of BMNP have difficult mountainous terrain to make survey. Hence, rangers are limited to particular fields and cannot cover all illegal activities inside the park. Therefore, not all of data could be represented spatially.

\section{Key References}

Burgman, M.; Carr, A.; Godden, L.; Gregory, R.; McBride, M.; Flander, L.; Maguire, L. (2011): Redefining expertise and improving ecological judgment. In Conservation Letters 4 (2), pp. 81-87

Malczewski, J.; Rinner, C. (2015): Multicriteria decision analysis in geographic information science. New York: Springer

Saaty, T. L.; Kearns, K. P. (1985): Analytical planning. The organization of systems. 1st ed. Oxford, New York: Pergamon Press 